\title{
SIMULASI PERANCANGAN DAN PEMBUATAN SHOP DRAWING PADA PEMBANGUNAN LIFT PENUMPANG KAPASITAS 20 ORANG/1350 KG
}

\author{
Alfian Hamsi ${ }^{1}$, Irfan A. Siregar ${ }^{2}$, M. Sabri ${ }^{3}$, Mahadi ${ }^{4}$, Tugiman ${ }^{5}$ \\ 1,2,3,4,5 Departemen Teknik Mesin Fakultas Teknik Universitas Sumatera Utara \\ Email: siregaralam20@yahoo.com
}

\begin{abstract}
Abstrak
Lift sangat diperlukan untuk mempercepat transport Karyawan antar lantai di gedung Camridge Mall. Metoda yang digunakan adalah metoda perancangan, mengunakan formula dan perhitungan pada motor pengerak, Number of Bend, umur tali baja yang sebagian datanya diambil dari survai lapangan sehingga diperoleh : ukuran hoistway : $2,600 \mathrm{~mm}$ x 2,400 mm, panjang lintasan : $24.500 \mathrm{~mm}$ kecepatan : $60 \mathrm{~m} / \mathrm{s}$, umur tali baja : 2,6 tahun, motor : 11,5 Hp. Hasil yang diperoleh adalah Shop Drawing lift penumpang kapasitas 20 orang/1350 kg tipe Machine Room Less. Kesimpulan dari perancangan ini adalah telah dirancang sebuah lift penumpang dengan kecepatan $60 \mathrm{~m} / \mathrm{s}$ dan menggunakan tali baja tipe $6 \times 37=222+1 \mathrm{C}$ di gedung Camridge Mall, Medan yang semuanya digambarkan pada Shop Drawing.
\end{abstract}

Kata kunci: Tali Baja, Perancangan, Number of Bend, Drawing

\section{PENDAHULUAN}

Elevator atau Lift merupakan angkutan transportasi vertikal yang digunakan untuk mengangkut orang atau barang. Lift umumnya digunakan di gedung-gedung bertingkat tinggi biasanya lebih dari tiga atau empat lantai. Gedung -gedung yang lebih rendah biasanya hanya menggunakan tangga atau escalator

Indonesia adalah negara yang sedang berkembang, dimana pada saat sekarang ini sedang mengadakan pembangunan di segala bidang untuk meningkatkan taraf hidup bangsa Indonesia. Pembangunan sarana dan pra sarana umum meliputi pemba-ngunan industri, perhubungan, pusat perbelanjaan atau mall, perkantoran, hotel, dan apartemen, seperti yang terjadi di Gedung Camridge Mall, Medan. Dilingkungan Mall ini juga telah tersedia tempat parkir, tempat perayaan acara-acara besar, toko, karena begitu luasnya gedung ini maka kesibukan setiap harinya yang dilakukan oleh karyawan dan pengunjung Mall tersebut, untuk itu dibutuhkan alat bantu untuk dapat mengefesiensi waktu.

Dari uraian dan pertimbangan pertimbangan ini maka penulis tertarik untuk merancang pembuatan Shop Drawing Elevator Penumpang kapasitas 20 orang/ $1350 \mathrm{~kg}$ dengan tinggi angkat 24,5 Meter. Karena Elevator ini sangat berpengaruh besar untuk kenyamanan dan keefisienan waktu bagi pengguna.

\section{TINJAUAN PUSTAKA}

\section{Mesin Pemindah Bahan}

Mesin pemindah bahan merupakan bagian terpadu perlengkapan mekanis dalam setiap industri modern. Desain mesin pemindah bahan yang beragam disebabkan oleh banyaknya jenis dan sifat muatan yang dipindahkan serta banyaknya operasi pemindahan yang akan mendukung produksi. Dalam setiap perusahaan, proses produksi secara keseluruhan sangat 
ditentukan oleh pemilihan jenis mesin pemindah bahan yang tepat pemilihan parameter utama yang tepat dan efisiensi operasinya. [1]

Faktor-faktor teknis penting yang digunakan dalam menentukan pilihan jenis peralatan yang digunakan dalam proses pemindahan bahan :

1. Jenis dan sifat muatan yang akan diangkat

Untuk muatan satuan (unit load) : bentuk, berat, volume, kerapuhan, keliatan, dan temperatur. Untuk muatan curah (bulk load) : ukuran gumpalan, kecenderungan menggumpal, berat jenis kemungkinan longsor saat dipindahkan, sifat mudah remuk (friability), temperatur, dan sifat kimia.

2. Kapasitas per jam yang dibutuhkan.

Kapasitas pemindahan muatan per jam yang hampir tak terbatas dapat diperoleh pada peralatan, seperti konveyor yang bekerja secara kontinu. Sedangkan pada peralatan lain yang mempunyai siklus kerja dengan gerak balik muatan kosong, akan dapat beroperasi secara efisien jika alat ini mempunyai kapasitas angkat dan kecepatan yang cukup tinggi dalam kondisi kerja yang berat, seperti truk dan crane jalan.

3. Arah dan jarak perpindahan.

Berbagai jenis peralatan dapat memindahkan muatan ke arah horizontal, vertikal, atau dalam sudut tertentu. Untuk gerakan vertikal diperlukan pengangkat seperti : crane, bucket elevator. Dan untuk gerakan horizontal diperlukan crane pada truk yang digerakkan mesin atau tangan, crane penggerak tetap, dan berbagai jenis konveyor. Ada beberapa alat yang dapat bergerak mengikuti jalur yang berliku dan ada yang hanya dapat bergerak lurus dalam satu arah.

4. Cara menyusun muatan pada tempat asal, akhir, dan antara.

Pemuatan ke kendaraan dan pembongkaran muatan ditempat tujuan sangat berbeda, karena beberapa jenis mesin dapat memuat secara mekanis, sedangkan pada mesin lainnya membutuhkan alat tambahan khusus atau bantuan operator.[2]

5. Karakteristik proses produksi yang terlibat dalam pemindahan muatan.

Gerakan penanganan bahan berkaitan erat, bahkan terlibat langsung dengan proses produksi. Misalnya : crane khusus pada pengecoran logam, penempaan dan pengelasan; konveyor pada pengecoran logam dan perakitan pada permesinan dan pengecatan.

6. Kondisi lokal yang spesifik.

Hal ini meliputi luas dan bentuk lokasi, jenis dan desain gedung, keadaan permukaan tanah, susunan yang mungkin untuk unit proses, debu, kelembaban lingkungan, adanya uap dan berbagai jenis gas lainnya, dan temperatur. [4]

\section{Elevator/ Lift}

Elevator / Lift adalah angkutan transportasi vertikal yang digunakan untuk mengangkut orang atau barang. Lift umumnya digunakan di gedung-gedung bertingkat tinggi, biasanya lebih dari tiga atau empat lantai. Gedung-gedung yang lebih rendah biasanya hanya mempunyai tangga atau escalator. Lift-lift pada zaman modern mempunyai tombol-tombol yang dapat dipilih penumpangnya sesuai lantai tujuan mereka, Terdapat tiga jenis mesin, yaitu Geared, Gearless, dan Machine Room Less

Lift ini, sering disebut elevator, yang merupakan alat angkut untuk mengangkut orang atau barang dalam suatu bangunan yang tinggi. Lift dapat dipasang untuk bangunan yang tingginya lebih dari 4 lantai, karena kemampuan orang untuk naik turun dalam menjalankan tugasnya hanya mampu dilakukan sampai 4 lantai. 


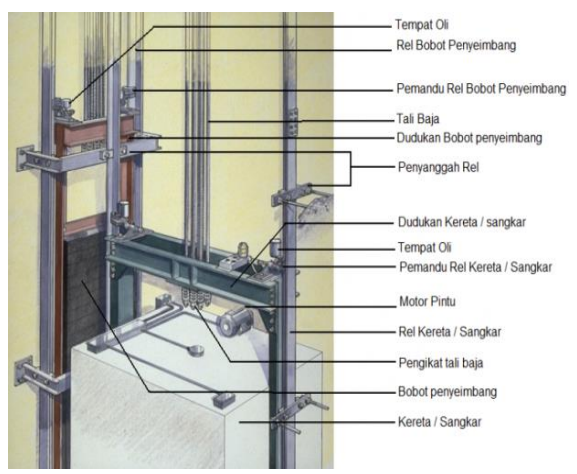

Gambar 1. Komponen pada Elevator

\section{Tali Baja}

Berbicara mengenai lift tentu tidak bisa dipisahkan dengan tali kawat baja. Beberapa kejadian fatal telah terjadi karena kurangnya pengetahuan mengenai tali kawat baja yang digunakan.

Tali baja berfungsi untuk mengangkat dan menurunkan beban serta memindahkan gerakan dan gaya. Tali baja adalah tali yang dikonstruksikan dari kumpulan jalinan serat-serat baja (steel wire) dengan kekuatan $\sigma b=130-200 \mathrm{~kg} / \mathrm{mm} 2$. Beberapa serat dipintal hingga menjadi satu jalinan (strand), kemudian beberapa strand dijalin pula pada suatu inti (core) sehingga membentuk tali

Tali baja banyak sekali digunakan pada mesin pengangkat karena dibandingkan dengan rantai, tali baja mempunyai keunggulan antara lain :
a. Lebih ringan dan lebih murah harganya
b. Lebih tahan terhadap beban sentakan, karena beban terbagi rata pada semua strand
c. Operasi yang tenang walaupun pada kecepatan operasi yang tinggi
d. Keandalan operasi yang tinggi
e. Lebih fleksibel dan ketika beban lengkungan tidak perlu mengatasi internal stress
f. Sedikit mengalami fatigue dan internal wear karena tidak ada kecenderungan kawat untuk menjadi lurus yang selalu menyebabkan internal stress.
g. Kurangnya kecenderungan untuk membelit karena peletakan yang tepat, pada drum dan puli, penyambungan yang lebih cepat, mudah dijepit (clip), atau ditekuk (socket)
h. Kawat yang patah setelah pemakaian yang lama tidak akan menonjol keluar sehingga lebih aman dalam pengangkatan dan tidak akan merusak
i. kawat yang berdekatan [3]

\section{Shop Drawing}

Shop Drawing atau gambar kerja adalah gambar teknis lapangan yang dipakai untuk acuan pelaksanaan suatu pekerjaan. Gambar-gambar ini bersifat detil dan menjadi pedoman pelaksana atau pemborong dalam melaksanakan pekerjaan suatu proyek

Kriteria baik sebuah gambar secara umum adalah mudah dipahami dan dapat dijadikan sebagai pedoman di lapangan dalam pelaksanaan pembangunan, kriteria tersebut diantaranya adalah 
a. Kop pada sisi bagian kanan berisi judul gambar, perusahaan, nama proyek, nomor gambar dan halaman.

b. Mempunyai bentuk dan ukuran setiap bagian konstruksi dengan jelas

c. Menggunakan skala gambar sehingga pada bagian konstruksi yang belum mempunyai penjelasan ukuran dapat dihitung menggunakan skala.

d. Gambar sesuai dengan kondisi lapangan dan dapat diaplikasikan dengan tepat dilapangan.

e. Mempunyai keterangan gambar seperti elevasi, jenis material dan penjelasan lainya.

f. Jelas dan tidak ada garis yang hilang atau rusak, hal ini dapat terjadi pada kelalaian dalam menggambar atau rusak setelah dilakukan penggandaan seperti pembuatan foto copy gambar.[4]

\section{Faktor yang mempengaruhi Umur Roda Puli \& Tali Baja}

Dasar untuk mendapatkan nilai aman tekanan satuan antara tali dan alur roda puli adalah umur roda puli. Untuk menentukan ukuran alur, kita harus mengetahui perbandingan antara tegangan bagian tali yang masuk (Son) dan keluar (Sout) saat priode gerak transien. Kapasitas fraksi alur roda puli tergantung pada bentuknya misalnya : kapasitas fraksi alur setengah lingkaran dengan potongan bawah tergantung pada sudut pusat potongan bawah.

Alur roda puli akan hilang fungsinya karena pengikisan pada dinding alur yang tergantung pada gelincir dan gerak elastik tali. Semakin besar kecepatan gerak tali dan semakin besar jumlah siklus kerja Elevator persatuan waktu dan semakin besar keausan yang terjadi. [3]

Dari hasil percobaan telah didapat besarnya tekanan satuan aman untuk roda puli penggerak. Nilai tekanan satuan (pada diagram) mengacu pada tali pintalan silang dan pada prakteknya nilai tadi tidak pernah melebihi $\mathrm{P} \max =100 \mathrm{Kg} / \mathrm{cm}^{3}$ untuk elevator barang. Untuk tali pintal paralel tekan satuan dapat ditingkatkan sebesar 25 persen bila nilai maksimum seperti pada tali pintalan silang digunakan. Untuk Elevator yang mesin penggeraknya di letakkan pada lantai atas (mesin dengan penggerak roda puli) nilai numerik percepatan dan perlambatan yang diijinkan ditentukan dan di tetapkan dengan percobaan. Perbandingan secara perkiraan dengan rumus sebagai berikut :

$\left(\frac{\text { Son }}{\text { Soff }}\right)$ st $\left(\frac{\mathrm{g}+\mathrm{a}}{\mathrm{g}-\mathrm{a}}\right)=\left(\frac{\text { S on }}{\text { Soff }}\right)$ dyn

Untuk mencegah keausan yang terlalu besar, beban aman pada setiap tali harus di periksa dengan rumus berikut :

$\mathrm{S}=\mathrm{d} \mathrm{D} \mathrm{P}_{\mathrm{maks}} \frac{\mu \cdot-\beta-\sin \beta}{8 \cos \hbar / 2}$

Dimana :

$\mathrm{d} \quad=$ diameter tali $(\mathrm{cm})$

$\mathrm{D}=$ diameter roda puli $(\mathrm{cm})$

Pmaks = tekanan satuan aman maksimum $\left(\mathrm{kg} / \mathrm{cm}^{2}\right)$ [1]

\section{METODOLOGI}

\section{Alat dan Bahan}


Yang menjadi objek dalam perancangan ini adalah Lift Penumpang Tipe P.20-CO-607FL-7ST (MRL Type) di gedung Camridge Mall, Medan. Perancangan shop drawing ini menggunakan software Autocad 2007. Adapun spesifikasi Elevator adalah sebagai berikut :

Car nos $\quad$ : \#P1

Duty : Passenger Elevator

$$
\text { (MRL Type ) }
$$

Quantity $\quad: 1$ (One) Unit

Capacity : $: 20$ Person/ $1350 \mathrm{Kg}$

Speed : $60 \mathrm{mpm}$

System Cntrol : AC-VVVf

Operation : Simplex

Floors : 7 (Seven)

Service Floors : 7 (Seven); B3, B2,

B1, LG, G, 1, 2

Opening Floors:7 (Seven); Front $=7$

Rear $=$ NIL

Door Type : 2Panel Centre Open

Travel : $24,500 \mathrm{~mm}$

Overhead : :4,600 mm

Pit Depth : : $1,500 \mathrm{~mm}$

M/C Location : above the hoistway

Power Supply : AC-3Ph/380V/50HZ

Lighting Supply: AC-1Ph/220V/50Hz

\section{Diagram Penelitian}

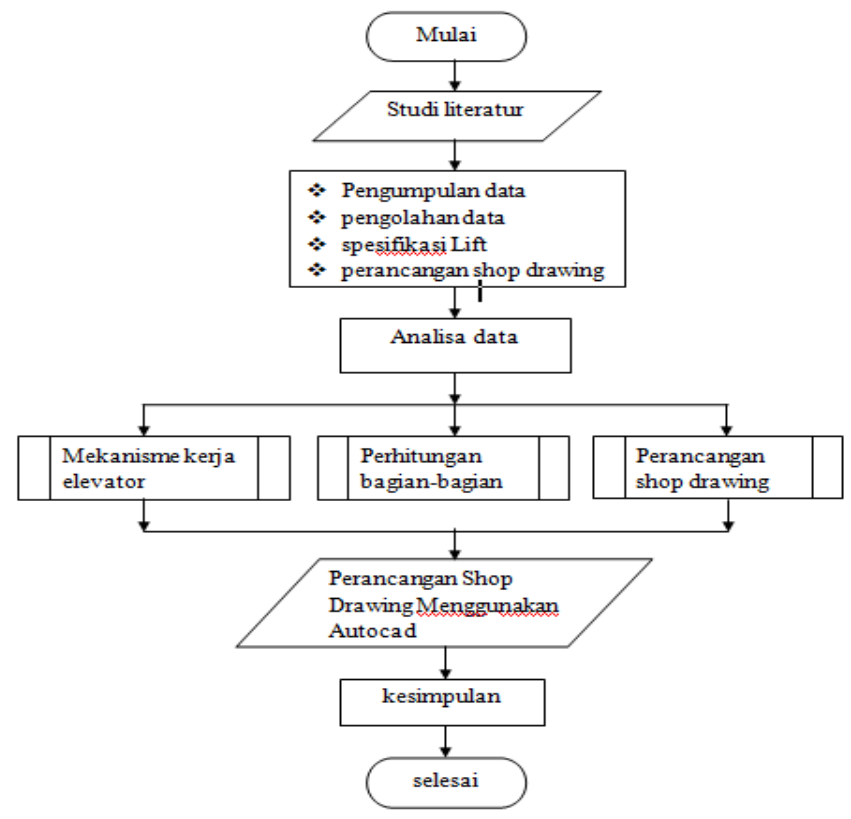

Gambar 2. Diagram Penelitian

\section{HASIL DAN PEMBAHASAN}

hasil dari perancangan Shop drawing ini sebagai berikut :

Panjang sangkar : $2.600 \mathrm{~mm}$ 
Lebar sangkar $\quad: 2.400 \mathrm{~mm}$

Tinggi Sangkar $: 2.500 \mathrm{~mm}$

Pit $\quad: 1.500 \mathrm{~mm}$

Over head $\quad: 4.600 \mathrm{~mm}$

Travel : $24.500 \mathrm{~mm}$
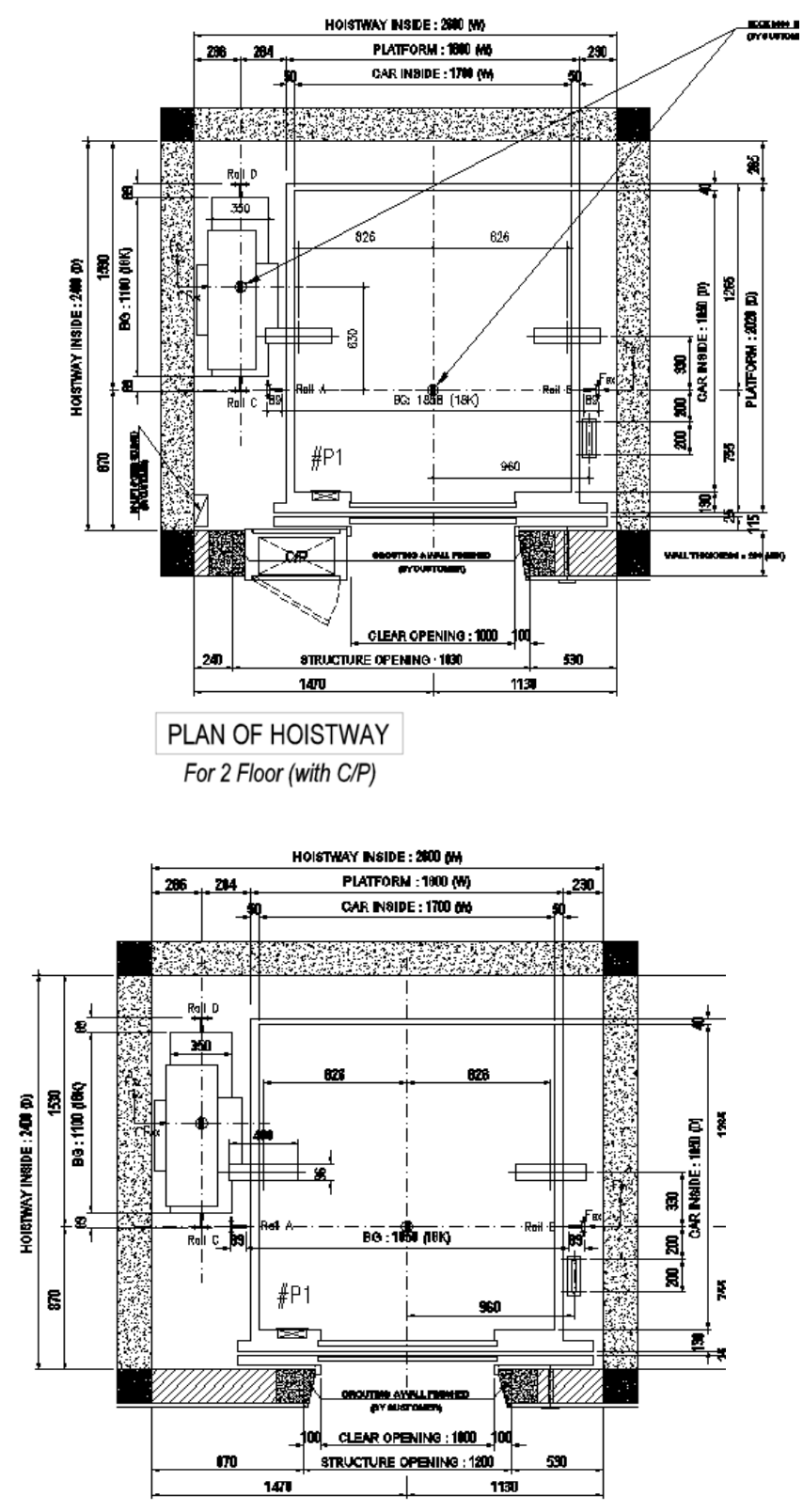

PLAN OF HOISTWAY

For B3, B2, B1, LG, G, 1, Floor

Gambar 3. Plan of Hoistway 


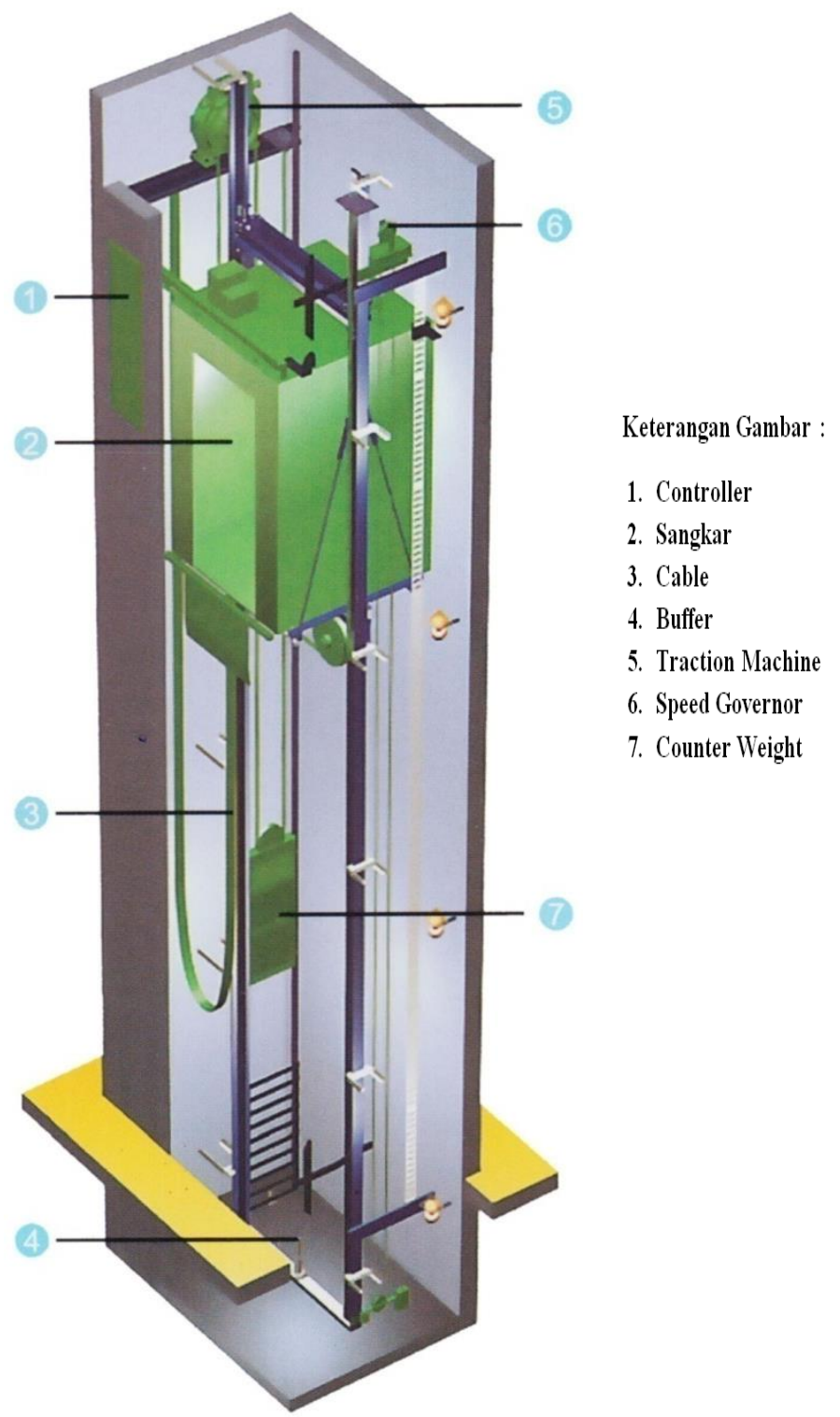

Gambar 4. Lift yang akan dirancang

\section{Menghitung Motor Penggerak}

Daya motor yang dibutuhkan untuk melayani kebutuhan sistem lift penumpang ini dapat dihitung dari persamaan berikut :

$$
\mathrm{N}_{\mathrm{st}}=\frac{(Q+G s+G c w)}{75 \eta t o t} \text { [4] }
$$

dimana :

$\mathrm{Q} \quad=$ kapasitas lift $=1350 \mathrm{~kg}$

Gs = bobot sangkar lift $=1200 \mathrm{~kg}$

$\mathrm{G}_{\mathrm{cwt}}=$ berat $\mathrm{CWT}=1875 \mathrm{Kg}$

$\mathrm{V}=$ kecepatan elevator $=60 \mathrm{~m} / \mathrm{min}$

Htot $=$ Efisiensi total elevator

Htot $=\eta$ hm. $\eta$ g.sh $. \eta d . s h$ 


$$
\begin{aligned}
\mathrm{N}_{\mathrm{st}} & =\frac{(1350 \mathrm{~kg}+1200 \mathrm{~kg}-1875 \mathrm{~kg})}{75 \times 0,7857} \\
& =11,5 \mathrm{hp} \approx 9 \mathrm{KW}
\end{aligned}
$$

dari perhitungan rumus tersebut maka diperoleh daya motor yang akan digunakan adalah 11,5 Hp.

\section{Perencanaan Counter Weight}

Dalam hal ini Counter Weight terbuat dari coran besi cor kelabu dengan desain yang berlapis yang akan memudahkan pengaturan bobot dan menyederhanakan perakitan. Dalam perencanaan ini, pengimbang sangat diperlukan karena pengimbang ini nantinya berfungsi untuk menghilangkan beban pada mesin pengangkat, bobot sangkar ditambah $0.4 \mathrm{~s} / \mathrm{d} 0.5$ dari muatan maksimum [1]

Laju aliran produksi dapat diperoleh dengan menggunakan persamaan:

$$
\begin{aligned}
\mathrm{G}_{\text {conter weight }} & =\mathrm{G}_{\text {sangkar }}+(0,5 . \mathrm{Q}) \\
& =1200 \mathrm{~kg}+0,5(1350 \mathrm{~kg}) \\
& =1875 \mathrm{~kg}
\end{aligned}
$$

Sehingga diperoleh berat conter weight adalah $1,875 \mathrm{~kg}$

\section{Perhitungan Tali Baja}

Pada perencanaan ini, tali baja yang dipakai adalah baja karbon tinggi JIS G 3521 dengan ukuran kekuatan putus $(\sigma \mathrm{b}) 160 \mathrm{~kg} / \mathrm{mm} 2$ dan dengan tipe: $6 \times 37=222+1 \mathrm{C}$ yang artinya sebuah tali dengan konstruksi yang terdiri dari 6 buah pintalan (strand) terdiri dari 37 Kawat baja (steel wire) dengan 1 inti serat

Jenis tali tipe: $6 \times 37=222+1 \mathrm{C}$ dipilih dengan pertimbangan bahwa semakin banyak kawat baja yang digunakan konstruksi tali maka akan lebih aman dari tegangan putus tali dan dapat menahan beban putus tali

Untuk mencari diameter satu kawat ditentukan dengan rumus :

$$
\mathrm{d}=1.5 \delta \sqrt{i}
$$

Dimana :

$$
\begin{array}{ll}
\mathrm{d} & =\text { diameter tali baja }(\mathrm{mm}) \\
\delta & =\text { diameter satu kawat } \\
\mathrm{i} & =\text { jumlah kawat dalam tali }
\end{array}
$$

\section{Maka :}

$$
\begin{aligned}
11 & =1.5 \delta \sqrt{22} 2 \\
\delta & =\frac{11}{1,5.14,90} \\
\delta & =0,5 \mathrm{~mm}
\end{aligned}
$$

Sehingga diperoleh diameter satu kawat adalah $0.5 \mathrm{~mm}$

\section{Luas Penampang Tali Baja}

Sebelum menghitung luas penampang tali baja, terlebih dahulu dilakukan perhitungan kekuatan putus tali baja yang digunakan.

Tabel 1. Menentukan NB tali baja 


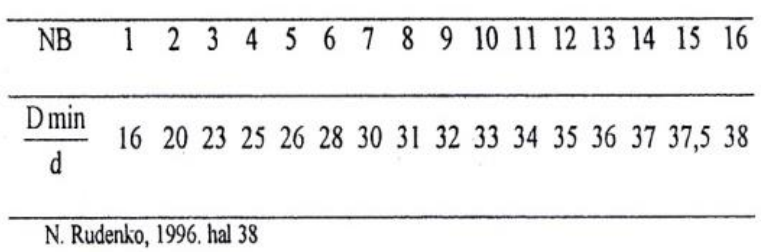

Dari tabel diatas dapat dilihat Jumlah lengkungan yang terdapat pada rangkaian tali NB $($ Number of Bend $)=9$ buah. Sehingga : $\quad D_{\min } / d=32$

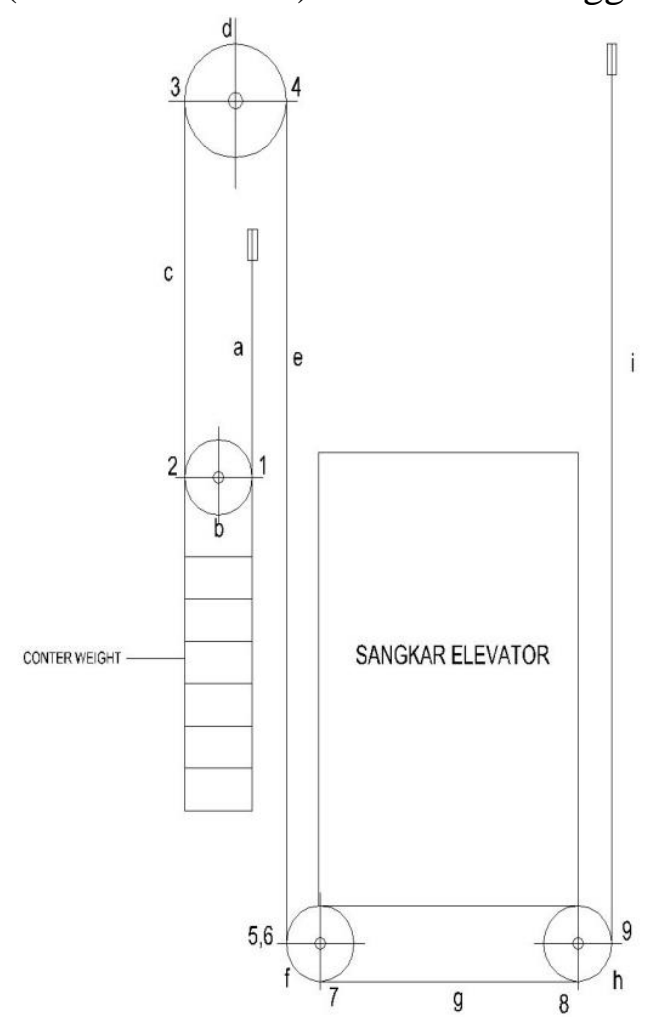

Gambar. 5 Sistem pemasangan tali pada puli dan jumlah lengkungan

Maka dengan mengambil desain tali dengan jumlah kawat $\mathrm{i}=222$, maka luas penampang tali dapat dihitung dari persamaan berikut :

$$
\mathrm{F}_{222}=\frac{\mathrm{s}}{\frac{\sigma \mathrm{b}}{\mathrm{K}}-\frac{\mathrm{d}}{\mathrm{Dmin}} \times 36000}
$$

Dimana :

$$
\begin{aligned}
\sigma \mathrm{b} & =\text { Kekuatan putus kawat baja } \\
& =160 \mathrm{~kg} / \mathrm{mm}^{2} \\
\mathrm{~K} & =\text { Faktor keamanan kawat baja } \\
\mathrm{S} & =\text { Tegangan tarik untuk satu tali }
\end{aligned}
$$

Maka :

$$
\begin{aligned}
\mathrm{F}_{222} & =\frac{607,39 \mathrm{~kg}}{\frac{16000 \mathrm{~kg} / \mathrm{cm}^{2}}{5,5}-\frac{1}{32} \times 36000} \\
& =0,3 \mathrm{~cm}^{2}
\end{aligned}
$$

Sehingga diperoleh luas penampang tali baja adalah $0,3 \mathrm{~cm}^{2}$ 


\section{Umur Tali Baja}

Umur kerja dari tali baja dipengaruhi oleh beberapa faktor yaitu :

a. Material

b. Metode Operasi

c. Tegangan - tegangan yang bekerja pada tali

d. Jumlah penggulungan tekuk, yaitu transmisi tali dari keadaan lurus ke keadaan bengkok atau sebaliknya.

Jumlah penggulungan tekuk yang dapat diterima tali baja sebelum mengalami kerusakan tergantung kepada tegangan yang bekerja dan perbandingan diameter puli dengan diameter tali baja yang dipergunakan.

Dalam hal menentukan umur tali baja, tidak terlepas pada faktor keausan tali baja (m) yang besarnya tergantung pada jumlah tekukan ( $\mathrm{NB}=$ Number Of Bend). Setiap tali baja hanya dapat mengalami lengkungan tertentu sepanjang umur kerja tali, sejumlah lengkungan tertentu yang telah melewati batas akan rusak dengan cepat, tetapi ada juga penyelidikan menyatakan umur tali kira- kira berbanding terbalik dengan jumlah lengkungan.

Dengan tersedianya diagram sistem puli tersebut, diagram gambar bentangan mekanismenya dan diagram lengkungan tali baja akan lebih mudah menentukan jumlah tekukannya (NB = Number of Bend). Setiap sistem puli majemuk dapat dianggap sebagai puli dengan dua tali terpisah yang dihubungkan dengan puli kompensasi, jumlah lengkungan tali puli majemuk dapat diperoleh dengan membagi dua jumlah titik total tempat bagian tali yang paralel masuk dan keluar puli.

Selanjutnya umur tali dapat dihitung dari persamaan sebagai berikut :

$\mathrm{N}=\frac{\mathrm{Z} 1}{\mathrm{a} \cdot \mathrm{z} 2 \cdot \beta}$ (bulan)

Dimana :

$\mathrm{Z}_{1}$ = penggulungan tekuk berulang yang diizinkan

$\mathrm{z}_{2}=$ jumlah tekukan berulang per siklus kerja

$=7$ buah

$\mathrm{a}=$ jumlah trip rata rata perbulan

$=1000$ (untuk peralatan ringan)

$\beta=$ faktor perubahan daya tahan tali akibat mengangkat muatan lebih rendah dari tinggi total dan lebih ringan dari muatan penuh.

$=0,5$

$\mathrm{N}=\frac{111000}{1000 \times 7 \times 0,5}$

$=31,71$ bulan atau 2,6 tahun

Dari perhitungan tersebut diperoleh bahwa umur tali adalah 31,71 bulan atau 2,6 tahun, selanjutnya tali baja harus diganti meskipun kondisinya masih terlihat baik. Jadi tali baja harus diganti sebelum 2,6 tahun ( $<2,6$ tahun) masa pemakaian, hal ini disebabkan oleh faktorfaktor yang mempengaruhi kekuatan tali, misalnya kondisi kerja tali akibat gesekan, kemungkinan beberapa tali sudah ada yang putus pada sepanjang lapisan serat atau kisar tali baja. 


\section{KESIMPULAN}

Berdasarkan hasil dan pembahasan dapat ditarik kesimpulan sebagai berikut:

1. Telah dirancang Shop Drawing Elevator kapasitas 20 orang/1350 kg dengan kecepatan 60 $\mathrm{m} / \mathrm{s}$ dan panjang travel : $24.500 \mathrm{~mm}$.

2. Dari Analisa yang dilakukan di peroleh Umur dari Tali Baja untuk Elevator kapasitas 20 Orang / $1350 \mathrm{Kg}$ adalah 31,71 Bulan (2,6 Tahun) dalam penggunaan normal,

3. Tegangan tarik izin tali diperoleh

$S_{\max }=1684,21 \mathrm{~kg}$, sedangkan dari perhitungan sebelumnya diperoleh bahwa tegangan tarik yang terjadi pada tali $\mathrm{S}=607,39 \mathrm{~kg}$, sehingga dapat disimpulkan bahwa tali aman terhadap beban tarik.

\section{DAFTAR PUSTAKA}

[1] N. Rudenko, (1996) Mesin Pengangkat : Edisi Ketiga, Erlangga, Ciracas-Jakarta 13740

[2] Lubomir Janovski, Elevator Mechanical Design, Principles and concepts, Czeehoslovakia, 1986

[3] Joseph. E. Shigley, Larry D. Mitchell, Perencanaan Teknik Mesin, Erlangga, Jakarta, 1986

[4] Sularso, Kiyokatsu Suga, Dasar Perencanaan dan Pemilihan Elemen Mesin, PT. Paradya Paramitha, Jakarta 1983. 